\title{
Advanced Bioreactor Treatments of Hydrocarbon-Containing Wastewater
}

\author{
Maria S. Kuyukina ${ }^{1,2, *} \mathbb{D}$, Anastasiya V. Krivoruchko ${ }^{1,2}{ }^{-1}$ and Irena B. Ivshina ${ }^{1,2}$ \\ 1 Microbiology and Immunology Department, Perm State University, Perm 614990, Russia; \\ nast@iegm.ru (A.V.K.); ivshina@iegm.ru (I.B.I.) \\ 2 Institute of Ecology and Genetics of Microorganisms, Perm Federal Research Center, Russian Academy of \\ Sciences, Perm 614081, Russia \\ * Correspondence: kuyukina@iegm.ru
}

Received: 29 November 2019; Accepted: 21 January 2020; Published: 24 January 2020

\begin{abstract}
This review discusses bioreactor-based methods for industrial hydrocarbon-containing wastewater treatment using different (e.g., stirred-tank, membrane, packed-bed and fluidized-bed) constructions. Aerobic, anaerobic and hybrid bioreactors are becoming increasingly popular in the field of oily wastewater treatment, while high concentrations of petroleum hydrocarbons usually require physico-chemical pre-treatments. Most efficient bioreactor techniques employ immobilized cultures of hydrocarbon-oxidizing microorganisms, either defined consortia or mixed natural populations. Some advantages of fluidized-bed bioreactors over other types of reactors are shown, such as large biofilm-liquid interfacial area, high immobilized biomass concentration and improved mass transfer characteristics. Several limitations, including low nutrient content and the presence of heavy metals or toxicants, as well as fouling and contamination with nuisance microorganisms, can be overcome using effective inocula and advanced bioreactor designs. The examples of laboratory studies and few successful pilot/full-scale applications are given relating to the biotreatment of oilfield wastewater, fuel-contaminated water and refinery effluents.
\end{abstract}

Keywords: oilfield produced water; refinery wastewater; bioreactor; hybrid systems; immobilized cells

\section{Introduction}

Hydrocarbon-containing wastewater is generated in large volumes in petroleum, metallurgical and transport industries, as well as in other water-intensive industries, agriculture and urban management. Oil production and refining processes consume large amounts of water and discharge hydrocarbon-contaminated wastewater streams, which are the main source of organic pollution of the environment. Petrochemical and metallurgical plants also produce complex wastewater streams, the volume and composition of which varies greatly depending on the raw materials and technologies used. Majority of the industrial wastes are hazardous as they contain toxic, mutagenic and carcinogenic substances. Consequently, industrial waste effluents typically require treatment before reuse or discharge to open water bodies. Stringent regulations on wastewater discharge are becoming stricter worldwide, with restrictions applied not only to industrial users but also to municipal wastewater treatment operations. Industry faces the challenge of reducing the wastewater it generates and attaining sustainable standards of operation. Water reuse and recycling define final concentrations of pollutants in wastewater and offer substantial potential for savings, for example, in petroleum refining [1]. Therefore, environmental legislation, on the one hand, and the needs of industry on the other, is the driving force in the development of advanced wastewater treatment facilities that provide high treatment efficiency at low capital, operational and maintenance costs. 
Urban transport and its services (repair shops, car washes, paint shops and filling stations) are a growing source of hydrocarbon-containing wastewater. Urban runoffs receive hydrocarbons mainly from transport but also from small industrial, commercial and domestic activities. Municipal wastewaters contain thousands organic compounds, among which petroleum hydrocarbons predominate. Also, emerging micropollutants (e.g., pharmaceuticals, personal care compounds, flame-retardants, biocides and pesticides) are increasingly detected in urban wastewaters [2].

Industrial and municipal effluents are treated using conventional methods in activated sludge and aerated lagoon systems. These processes suffer from serious operational problems, while novel techniques, for example, membrane bioreactors are applied. Treatment of oily wastewater usually has two stages, firstly, pre-treatment to reduce oil, grease and suspended materials. Secondly, an advanced treatment stage to degrade and decrease the pollutants to acceptable discharge values. The complexity of the wastewater composition and stringent discharge limits require combinations of several treatment methods. There are several reviews published recently on the treatment of petrochemical wastewater [3-5] including biological methods [6,7]. This review focuses on advanced bioreactor technologies, including hybrid and integrated physico-chemical and biological systems.

\section{Sources and Impacts of Hydrocarbon-Containing Wastewater}

Potential sources of hydrocarbon-containing wastewater are petroleum, metallurgical and transportation industries, which are concerned about the separation and recovery of oil from water and the treatment of oily wastewater. Large volumes of wastewater having high concentrations of free and emulsified oil are generated from oil and gas fields, refineries and petrochemical plants, thus leading to severe contamination of soil and water bodies.

Oilfield wastewater typically includes produced water, used drilling fluid and wastewater after washing the drilling/extraction equipment and storage tanks. The wastewater volume has increased worldwide with increasing oil and gas production despite the large proportion of produced water being reinjected into wells or pumped underground for disposal [8-10]. The amount of produced water depends on the extraction technology, the reservoir characteristics and the rate of oil extraction. In different sites, the amount of water may be $2-5$ or up to 50 times more than the amount of oil produced [10].

Oilfield wastewater is a complex mixture of oil, water, suspended and dissolved solids. It may contain high mineral salt concentrations, heavy metals, naturally occurring radioactive elements and chemical additives used in drilling and operating the well (surfactants, biocides, $\mathrm{pH}$ controlling agents, etc.) $[8,10]$. Of the oilfield wastewater constituents, polycyclic aromatic hydrocarbons (PAHs), phenols, heavy metals and radioactive elements are of environmental concern [8] (Table 1).

Table 1. Toxic Organic and Inorganic Compounds Present in Major Hydrocarbon-Containing Wastewater Streams.

\begin{tabular}{|c|c|c|c|}
\hline Type of the Effluent & Toxic Organic Components & Toxic Inorganic Components & References \\
\hline Oilfield produced water & $\begin{array}{c}\text { Benzene, toluene, ethylbenzene, xylene } \\
\text { (BTEX), PAHs, phenols, surfactants, } \\
\text { biocides }\end{array}$ & $\begin{array}{l}\text { Mineral salts (salinity up to } \\
300 \% \text { ), heavy metals, } \\
\text { radioactive elements }\end{array}$ & {$[8,10]$} \\
\hline Refinery wastewater & $\begin{array}{c}\text { BTEX, PAHs, phenols, MTBE, } \\
\text { naphthenic acids, methanol, ketones, } \\
\text { ethers, surfactants }\end{array}$ & $\begin{array}{l}\text { Ammonia, cyanides, hydrogen } \\
\text { sulphide, halides, sulphides, } \\
\text { mercaptans, heavy metals, } \\
\text { radioactive elements }\end{array}$ & {$[3,11]$} \\
\hline $\begin{array}{l}\text { Petrochemical } \\
\text { wastewater }\end{array}$ & $\begin{array}{l}\text { Chlorinated and nitro-benzenes, } \\
\text { phenols, pesticides, brominated organic } \\
\text { compounds, estrogens, PAHs, PCBs, } \\
\text { phthalates, anilines, tenside, thioanisol, } \\
\text { indole, dimethyl- and } \\
\text { trimethylpyrazines, } \\
\text { dimethylpyrimidine, dimethyl- and } \\
\text { trimethylpyridines }\end{array}$ & $\begin{array}{l}\text { Heavy metals, ammonia, } \\
\text { hydrogen sulphide, } \\
\text { mercaptans, cyanides }\end{array}$ & [12] \\
\hline
\end{tabular}


Table 1. Cont.

\begin{tabular}{|c|c|c|c|}
\hline Type of the Effluent & Toxic Organic Components & Toxic Inorganic Components & References \\
\hline Metallurgy wastewater & $\begin{array}{l}\text { BTEX, phenols, quinolines, PAHs, } \\
\text { hydrazines and imine-carbohydrazides, } \\
\text { thiophenes }\end{array}$ & $\begin{array}{l}\text { Heavy metals, acids/alkalines, } \\
\text { radioactive metals, ammonia, } \\
\text { cyanide }\end{array}$ & [13] \\
\hline Urban runoff & $\begin{array}{c}\text { PCBs, di-(2-ethylhexyl)phthalate } \\
\text { (DEHP), linear alkyl benzene } \\
\text { sulphonates (LAS), nonylphenol } \\
\text { ethoxylates (NPE), dioxins (PCDD), } \\
\text { furans, brominated } \\
\text { diphenyl ethers (PBDEs), } \\
\text { pharmaceuticals, personal care } \\
\text { compounds, flame-retardants, biocides } \\
\text { and pesticides }\end{array}$ & Heavy metals, salts, acids & {$[2,14]$} \\
\hline
\end{tabular}

Petroleum refinery effluents are generated in oil refinery processes that convert crude oil into numerous refined products, such as liquefied petroleum gas, fuels, lubricants and petrochemical intermediates. These processes consume a large volume of water ranged between $0.2 \mathrm{~m}^{3} / \mathrm{t}$ and $25 \mathrm{~m}^{3} / \mathrm{t}$ of feedstock refined for the European refineries [11] with 10\% reduction due to efficient water reuse and recycling [1]. The amount and composition of the refinery wastewater vary considerably depending on crude oil characteristics, plant configuration and process designs. Regardless of configuration, the main wastewater stream is generated from cooling systems, distillation, hydrotreating and desalting [3]. In particular, the water used in crude oil processing (e.g., desalting, distillation and cracking) or washing and cleaning operations comes into direct contact with either crude oil or various hydrocarbon fractions, and thus representing the main organic load. On the other hand, the water used for cooling systems and boilers is usually less contaminated but quantitatively represents the largest part (more than $50 \%$ on average) of the wastewater effluent.

Crude oil and hydrocarbons are the main pollutants found in wastewater generated by refineries. These petroleum compounds consist of three main hydrocarbon groups-paraffins (straight chained $n$-alkanes from $C_{1}$ to $C_{40}$ and branched isoalkanes), naphthenes or cycloparaffins (naphthene rings contain typically 5 or 6 carbon atoms; more condensed dicyclonaphthenes $C_{8}$ and $C_{9}$ are present in addition to monocyclonaphthenes) and aromatics (having the benzene ring comprising alternate double and single bonds with adjacent carbon atoms; monocyclic and polycyclic aromatics). In addition, naphthenic acids (a mixture of alkyl-substituted acyclic, monocyclic and polycyclic carboxylic acids with an aliphatic chain of 9 to 20 carbon atoms), which are known to cause toxic effects and are difficult to remove from refinery wastewater [15]. Other pollutants found in wastewater include hydrogen sulphide, ammonia, phenols, benzene, cyanides, and suspended solids containing metals and inorganic compounds (e.g., halides, sulphates, phosphates, sulphides) [11]. Petroleum refinery effluents are priority pollutants due to their high PAH contents, which are toxic and tend to be more persistent in the environment [3].

Another major source of oily wastewater is the metallurgical industry. Most of the oily waste comes from metal-working or metal-forming operations, such as coke quenching, steel rolling, solvent extraction and electroplating [13]. Oil-in-water and water-in-oil emulsions of different compositions, ranging from trace of oil in water to trace of water in oil, are used as cooling and lubricating agents; they also provide corrosion protection for machined parts and machining tools. Such spent oily water emulsions can be highly viscous and often severely hamper wastewater treatment plant capabilities, thus causing increased maintenance costs and energy consumption. Also, solvent extraction and electro-deposition processes used in hydrometallurgy consume myriads of highly toxic organic substances as extractants, diluents, matrix modifiers, flocculants, brightening agents, acid fog inhibitors. A general feature of metallurgical process-related effluents is the complex composition and relatively high toxicity. The primary components of metallurgical oily wastewaters are emulsified oil, emulsifiers, degreasing agents, surfactants, solvents, suspended solids, metals and acids/alkalines [13]. For example, the wastewater from rare earth metallurgy contains radioactive metals, such as thorium, uranium, 
radium, due to the paragenetic relation of these elements with rare earth metals. To treat these oily wastewaters, the hybrid processes consolidating the advantages of two or more technologies are often employed because of high metal concentrations and the recalcitrant nature of organic fractions.

Large amounts of oily wastewater are produced by the transportation industry, namely, road, rail, marine and air transport. The emergence of various kinds of automobiles or vehicles led to the considerable increase in the use of motor fuels and oils, which are the important sources of hydrocarbon pollution in wastewater. Furthermore, the car wash, engine wash, paint spraying workshop or petrol station wastes also contain residual hydrocarbons. Inputs of organic contaminants and metals to the urban wastewater system occur from three generic sources: domestic, commercial and urban runoffs. Typical domestic wastewater contains $10-50 \mathrm{mg} / \mathrm{L}$ of oil and grease (O\&G). Over 6000 organic compounds have been detected in raw water sources within European urban areas, most of which are due to human activities [14]. While some of these are highly persistent, others are easily biodegradable. These organic compounds include aliphatic and aromatic hydrocarbons, PAHs, fatty acids, ketones, phthalate esters, plasticizers and other polar compounds. Solvent extractable organics are dominated by petroleum hydrocarbons, which arise from motor oil leaks, degraded asphalt and worn tires from the roads. Most toxic and recalcitrant organic pollutants found in urban wastewaters include PAHs, polychlorinated biphenyls (PCBs), di-(2-ethylhexyl)phthalate (DEHP), linear alkyl benzene sulphonates (LAS), nonylphenol ethoxylates (NPE), dioxins (PCDD) and furans (PCDF). Also, emerging micropollutants (e.g., pharmaceuticals, personal care compounds, flame-retardants, biocides and pesticides) are increasingly detected in urban wastewaters [2].

While starting in the 1990s, the strict control of organic pollutants from small industrial, domestic and transport sources in Europe allowed the reduction of the levels of urban contamination; the concentrations of petroleum hydrocarbons in sewage treatment influents remain quite high. Moreover, some organic substances, with the potential to exert a health or environmental hazard, were identified in sludges and sewage treatment effluents $[14,16]$, thus requiring more regulatory, economic and educational instruments to mitigate the problem of wastewater pollution. According to the Rules of Cold Water Supply and Sanitation approved by the Russian Federation Government Decree No. 644 (new edition from 26 July 2018), new standards for the concentrations of pollutants in wastewater allowed to discharge to a centralized sewerage system were established. In particular, the maximum allowable concentration $(\mathrm{mg} / \mathrm{L})$ of petroleum products is 10 , fats- -50 , volatile organic compounds (toluene, benzene, acetone, methanol, butanol, propanol, their isomers and alkyl derivatives) - 20, suspended solids - 300, synthetic surfactants - 10 , phenols 5, and polychlorinated biphenyls -0.001 . These new regulations have prompted dozens of local treatment facilities to be established by transport, small industrial and road construction companies, in which the advanced and cost-efficient technologies of wastewater purification are applied [17].

It is worth noting that the environmental and human health risks of hydrocarbon pollutants are determined by their toxicity, how they spread if released into the environment, how long they stay in the environment, and whether they bioaccumulate in the food chain. Therefore, understanding the fate and transport of contaminants is crucial for risk assessment, while this analysis can be very complicated because it requires the best approximation of the environmental chemistry of hydrocarbon contaminants (e.g., biodegradability, hydrophobicity) and the environment at the site (e.g., geology, geochemistry). At the heart of this problem is the concept of bioavailability [18]. If a pollutant is present in soil or water but is not available to the biota, then it presents minimal risk (unless chemical conditions change that can subsequently increase the bioavailability). However, measuring bioavailability is often a difficult task and cannot be estimated directly from the total pollutant concentration since the bioavailability level can vary significantly. Bioavailability is indirectly related to partitioning phenomena, biodegradability and toxicity [19] and it is also dependent on the organism exposed.

While most potential environmental impacts related to oil and gas industry activities are already well documented, there are several uncertainties concerning the long-term effects of oilfield and refinery wastewater releases, for example, the effects of endocrine disrupting, carcinogenic and radioactive 
components with respect to toxic concentrations, bioaccumulation, fertilization, and so forth $[20,21]$. A major concern is the release of hydrocarbon- and chloride-rich wastewater into soil, aquatic and wetland ecosystems $[8,22,23]$.

In general, the hydrocarbon-containing wastewater has various impacts to the soil environment, which include reduction in crop yield, shortage of oxygen and detrimental effects on wild plants and animals. The presence of petroleum hydrocarbons in water can reduce soil fertility because of adverse effects on physicochemical characteristics of soil, microbial populations and plant growth, which could lead to the reduction in crop yield [24,25]. Also, heavy metal contents in soil repeatedly irrigated with treated petroleum wastewater can be significantly increased, thus leading to the bioaccumulation of these toxic elements in the food chain [26]. Major risks associated with treated produced water used in agricultural irrigation were determined as dissolved formation minerals (i.e., salts and sodium) and metalloids, while these risks are also related to irrigation with both municipal and industrial wastewaters that are often saline and sodic [27].

The discharge of hydrocarbon-polluted wastewater into receiving water bodies poses threat to marine and freshwater environments, especially to vulnerable aquatic ecosystems of northern regions, where natural biodegradation processes are slower due to low temperatures. Most toxic components, for example, alkylphenols and PAHs, from produced water can accumulate in phyto- and zooplankton populations, thus transmitted through the food chain to higher marine organisms and affect their vital functions [8]. Also, salinization of freshwater resources leads to increasing chloride and sodium concentrations, which could have toxic effects on fish, macroinvertebrates, amphibians and other salinity-intolerant species [28].

\section{Treatment of Hydrocarbon-Containing Wastewater}

It should be noted that concentrations of petroleum hydrocarbons in wastewater may decrease due to natural processes of decomposition and chemical oxidation, evaporation and biological degradation by native microflora. In natural environments, however, these processes are relatively slow. To enhance the oil contaminant removal from wastewater, the mechanical, chemical, physicochemical and biological methods, as well as their combinations, are employed, providing the required purification rate at reasonable costs. Importantly, the choice of a treatment method in each case is determined by the source of wastewater, the diversity and levels of contaminants, and the subsequent intended use of treated effluents. Recent developments in treatment technologies for petrochemical wastewater and produced water from oil and gas industries are reviewed by Wei et al. [5]. Treatment of petroleum wastewater usually involves two stages, firstly, physical (mechanical) pre-treatment to remove free oil \& grease fractions and suspended particles. Secondly, an advanced treatment, usually involving a combination of different physicochemical and biological methods, to decrease the pollutant level to acceptable discharge values.

The sedimentation treatment, which is used to separate bulk free oil from water, is mechanically achieved by gravity in API (American Petroleum Institute) or CPI (Corrugated Plate Interceptor) separators and dissolved air floatation (DAF) units. During wastewater sedimentation, insoluble solids are also removed, which prevents clogging and wearing of devices used in subsequent treatment stages. Mechanical treatment techniques, while allowing the reuse of roughly purified water in the operation cycle, are inefficient in the recovery of finely dispersed oil, dissolved organics, metals and colloids. The mechanical step is followed by the physiochemical step, in which small-sized suspended solids and dispersed oil are further reduced by agglomeration into large-sized particles to ease the removal by filtration, sedimentation or floatation [3]. However, settling of petroleum products as insoluble non-utilizable sediments (sludges) performed using expensive chemicals (particularly coagulants and flocculants) entails costly disposal of the resulting sludge and may lead to secondary contamination of the treated water [9].

Several techniques that are used as advance treatment methods for reducing the effluent contamination level to allowable limits for discharge into water bodies include membrane filtration 
and electrodialysis [29,30], adsorption [31], biological systems [5], advanced oxidation [5] and electrochemical processes [32]. Of these, sorption methods are advantageous because their performance and cost efficiency are compatible with other techniques for petroleum removal, and sorbents are reusable after regeneration. Sorbents are porous materials, both natural (activated carbon, sawdust, peat, perlite, clay, sand) and synthetic (polyurethane foam, ceramic materials, synthetic fiber) with high affinity for the targeted pollutants, good adsorption capacity and hydrophilic-lipophilic properties. The choice of the material relies on its ecological safety and availability in the region [31,33].

Currently used biological methods are activated sludge systems [34,35], aerated lagoons and wetlands [36,37]. Laboratory-proved technologies include aerobic [38-41], anaerobic [42-44] and hybrid [15,45-47] bioreactors. However, because of heavy petroleum hydrocarbon load, high salinity, low nutrient concentrations and toxicants present, the current activated sludge bioprocesses often suffer from operation problems, such as low removal rate and high suspended solid concentration [48]. To overcome these problems, advanced bioreactor systems and selected cultures with enhanced degradative capabilities and tolerance to environmental stresses can be used.

\section{Advanced Bioreactors for Hydrocarbon-Containing Wastewater Treatment}

\subsection{Aerobic Bioreactors}

Bioreactor-based technologies allow more precise control and management of biodegradation parameters, such as temperature, $\mathrm{pH}$, oxygen, nutrient and water contents, homogenous distribution of hydrophobic contaminants and biomass in the reactor volume, which leads to increased mass transfer and reaction rates. Aerobic bioreactors are intensively explored for the industrial effluent treatment due to their easy operation, high microorganism growth and organic carbon oxidation rates and resistance to toxic effects. Several laboratory and pilot studies were performed to treat oily wastewaters using aerobic bioreactors of various configurations and different microbial inocula. Selected examples of aerobic bioreactors used for hydrocarbon-containing wastewater treatment are shown in Table 2.

Table 2. Aerobic Bioreactors Used for Hydrocarbon-Containing Wastewater Treatment.

\begin{tabular}{|c|c|c|c|c|}
\hline Wastewater Type & $\begin{array}{c}\text { Bioreactor } \\
\text { Configuration }\end{array}$ & Operational Conditions & Treatment Efficiency & Reference \\
\hline $\begin{array}{l}\text { Petroleum refinery } \\
\text { wastewater }\end{array}$ & $\begin{array}{l}\text { Continuously } \\
\text { stirred tank }\end{array}$ & $\begin{array}{l}\text { Acclimatized indigenous } \\
\text { microbial consortium. } \\
\text { Experimental period of } 225 \text { days }\end{array}$ & $\begin{array}{c}\text { Removal of } 95 \% \text { COD, } \\
97.5 \% \mathrm{TPH}\end{array}$ & [40] \\
\hline $\begin{array}{l}\text { Synthetic } \\
\text { petrochemical } \\
\text { wastewater }\end{array}$ & SBR & $\begin{array}{l}\text { Sludge from municipal AS plant. } \\
3 \text { cycles at HRT of } 15 \text { days. }\end{array}$ & $\begin{array}{c}\text { Removal of } 59-88 \% \\
\text { COD, } 76-90 \% \text { for } \mathrm{Hg} \\
96-98 \% \text { for } \mathrm{Cd}\end{array}$ & [49] \\
\hline $\begin{array}{l}\text { Petroleum refinery } \\
\text { wastewater }\end{array}$ & Two-stage SBR & $\begin{array}{c}\text { Sludge from domestic sewage } \\
\text { treatment work. } \\
\text { Two stage operation with } \\
\text { methanol as co-substrate. }\end{array}$ & $\begin{array}{c}97.5 \% \text { of COD removal } \\
\text { and complete O\&G } \\
\text { removal }\end{array}$ & {$[50]$} \\
\hline $\begin{array}{c}\text { Synthetic petroleum } \\
\text { wastewater }\end{array}$ & MSBR & $\begin{array}{c}\text { Three parallel } 10-1 \text { reactors. HRT } \\
\text { values of } 8,16 \text { and } 24 \mathrm{~h} .\end{array}$ & $\begin{array}{l}\text { Hydrocarbon removal > } \\
97 \%\end{array}$ & [51] \\
\hline $\begin{array}{l}\text { Shipboard slop } \\
\text { wastewater }\end{array}$ & MBR and MBBR & $\begin{array}{l}\text { Sludge from municipal AS plant. } \\
\text { Polyurethane sponges as biofilm } \\
\text { carriers. HRT in the range of } \\
12-15 \mathrm{~h} .\end{array}$ & $70-85 \%$ of TPH removal & [52] \\
\hline $\begin{array}{l}\text { Oilfield produced } \\
\text { water }\end{array}$ & MBBR & $\begin{array}{l}\text { Sludge from petrochemical } \\
\text { wastewater treatment plant. } \\
\text { Sepiolite-modified ceramic foam } \\
\text { carriers for biofilm. HRT } \\
\text { ranging from } 36 \text { to } 10 \mathrm{~h} \text {. }\end{array}$ & $\begin{array}{c}\text { Maximum COD removal } \\
\text { of } 74-77 \%\end{array}$ & [53] \\
\hline
\end{tabular}


Table 2. Cont.

\begin{tabular}{|c|c|c|c|c|}
\hline Wastewater Type & $\begin{array}{l}\text { Bioreactor } \\
\text { Configuration }\end{array}$ & Operational Conditions & Treatment Efficiency & Reference \\
\hline $\begin{array}{l}\text { Petrochemical } \\
\text { wastewater }\end{array}$ & $\begin{array}{l}\text { Full-scale CFIC } \\
\text { biofilm technology }\end{array}$ & $\begin{array}{l}\text { Highly packed polymer biofilm } \\
\text { carriers (over } 90 \% \text { filling ratio). } \\
\text { COD ranging from } 7 \text { to } 35 \mathrm{~g} / \mathrm{L} \text {, } \\
\text { flow rate of } 240 \mathrm{~m}^{3} / \text { day. }\end{array}$ & Over $90 \%$ COD removal & [7] \\
\hline $\begin{array}{l}\text { Oilfield wastewater } \\
\text { before desalination }\end{array}$ & BAF & $\begin{array}{l}\text { Commercial oil-degrading } \\
\text { inocula B350M and B350 } \\
\text { immobilized on a patented } \\
\text { poly-ammoniacum carrier. }\end{array}$ & $\begin{array}{c}\text { Removal of } 64-78 \% \text { TOC, } \\
86-94 \% \text { oil and } 84-90 \% \\
\text { PAHs }\end{array}$ & [39] \\
\hline $\begin{array}{l}\text { Oilfield produced } \\
\text { water }\end{array}$ & BAF & $\begin{array}{l}\text { Spent and new GAC carriers for } \\
\text { indigenous biofilm. }\end{array}$ & $\begin{array}{l}81 \% \text { COD removal in } \\
24 \mathrm{~h}\end{array}$ & [54] \\
\hline $\begin{array}{l}\text { Oilfield produced } \\
\text { water }\end{array}$ & $\begin{array}{l}\text { Batch stirred tank } \\
\text { bioreactor }\end{array}$ & $\begin{array}{l}\text { Acclimated indigenous } \\
\text { halophilic microorganisms. }\end{array}$ & $\begin{array}{l}>60 \% \text { degradation of } \\
\text { crude oil }\end{array}$ & [55] \\
\hline $\begin{array}{l}\text { Carwash wastewater } \\
\text { with amended } \\
\text { lubricant }\end{array}$ & $\begin{array}{l}\text { Internal loop airlift } \\
\text { bioreactor }\end{array}$ & $\begin{array}{l}\text { Chitosan-immobilized } \\
\text { Sphingobium sp. P2 (TISTR 2006). } \\
\text { HRT of } 2.0 \mathrm{~h} \text { for over } 70 \text { days. }\end{array}$ & $\begin{array}{l}\text { Removal of } 85 \pm 5 \% \mathrm{TPH} \\
\quad \text { and } 73 \pm 11 \% \mathrm{COD}\end{array}$ & [56] \\
\hline $\begin{array}{l}\text { Oilfield produced } \\
\text { water }\end{array}$ & $\begin{array}{l}\text { Continuously } \\
\text { operated stirred } \\
\text { tank reactor }\end{array}$ & $\begin{array}{c}\text { Simultaneous } n \text {-alkane } \\
\text { biodegradation and production } \\
\text { of neutral lipids by Alcanivorax } \\
\text { borkumensis SK2. }\end{array}$ & $\begin{array}{l}\text { Alkane removal up to } \\
\qquad 99.6 \%\end{array}$ & [57] \\
\hline $\begin{array}{l}\text { Petroleum refinery } \\
\text { wastewater }\end{array}$ & FBB & $\begin{array}{l}\text { Polypropylene particles } \\
\text { inoculated with refinery } \\
\text { activated sludge. }\end{array}$ & $90 \%$ COD reduction & [38] \\
\hline Urban wastewaters & FBB & $\begin{array}{c}\text { Pelleted mycelium of the white } \\
\text { rot fungus Trametes versicolor } \\
\text { ATCC } 42530 \text {. }\end{array}$ & $\begin{array}{l}100 \% \text { removal of } 7 \text { out of } \\
10 \text { pharmaceuticals }\end{array}$ & [58] \\
\hline $\begin{array}{l}\text { Synthetic petroleum } \\
\text { wastewater }\end{array}$ & FBB & $\begin{array}{c}\text { Hydrophobized sawdust } \\
\text { immobilized Rhodococcus ruber } \\
\text { IEGM } 615 \text { and Rhodococcus } \\
\text { opacus IEGM } 249 \text {. }\end{array}$ & $\begin{array}{l}70-100 \% \text { n-alkane } \\
\text { removal, } 46-70 \% \\
\text { removal of } 2-3 \text {-ring } \\
\text { PAHs }\end{array}$ & [59] \\
\hline Oilfield wastewater & FBB & $\begin{array}{c}\text { Hydrophobized sawdust } \\
\text { immobilized Rhodococcus ruber } \\
\text { IEGM } 615 \text { and Rhodococcus } \\
\text { opacus IEGM } 249 \text {. }\end{array}$ & $\begin{array}{l}70 \% \text { removal of alkanes } \\
\text { and PAHs, } 75-96 \% \\
\text { removal of heavy metals }\end{array}$ & [41] \\
\hline $\begin{array}{l}\text { Highly saline oilfield } \\
\text { wastewater }\end{array}$ & FBB & $\begin{array}{c}\text { Poly(vinyl alcohol) cryogel } \\
\text { immobilized Rhodococcus ruber } \\
\text { IEGM } 231 \text { and Rhodococcus } \\
\text { opacus IEGM } 263 .\end{array}$ & Removal of $64-82 \% \mathrm{TPH}$ & {$[60]$} \\
\hline
\end{tabular}

A continuously stirred tank bioreactor was applied to treat hydrocarbon-rich wastewater from a petroleum refinery site using an acclimatized indigenous microbial consortium [40]. The performance of the bioaugmented reactor was demonstrated by the reduction of chemical oxygen demand (COD) rates up to $95 \%$ and residual total petroleum hydrocarbon (TPH) concentration to $97.5 \%$ (from $320 \mathrm{mg} / \mathrm{L}$ to $8 \mathrm{mg} / \mathrm{L}$ ). Malakahmad et al. [49] evaluated the performance of a sequencing batch reactor (SBR) with pre-grown activated sludge microorganisms to treat synthetic petrochemical wastewater containing mercury and cadmium. They found that COD removal and microbial population growth were inhibited by high metal concentrations, while metal removal rates were $76-90 \%$ for $\mathrm{Hg}$ and $96-98 \%$ for $\mathrm{Cd}$. A two-stage SBR system was applied for treatment of refinery wastewater with high COD and O\&G concentrations (up to $7.8 \mathrm{~g} / \mathrm{L}$ and $13,4 \mathrm{~g} / \mathrm{L}$, respectively) using a gradual increase in wastewater load and methanol as the co-substrate [50]. This strategy enabled a short acclimation period of the sludge, resulting in $97.5 \%$ of COD removal and complete O\&G removal.

It should be noted that while the SBR technology is widely used for biotreatment of petroleum refinery wastewater, it cannot remove suspended solids (SS) completely, so the settleability of the activated sludge is adversely affected. The application of membrane separation instead of the settling phase of the SBR realized in a membrane sequencing batch reactor (MSBR) technology results in an effluent with negligible SS content. However, membrane fouling is a major problem in both membrane 
bioreactors and MSBRs, thus increasing considerably the operational costs due to the periodical physical or chemical membrane cleaning. Dickhout et al. [61] proposed a fouling mechanism for oily wastewater and they found that oil droplets were coalescing on the membrane surface, forming a continuous oil layer on the surface, different from a traditional cake layer made of separate particles. Shariati et al. [51] tested the effect of hydraulic retention time (HRT) on the performance and fouling characteristics of the MSBR used to treat synthetic petroleum wastewater with an average hydrocarbon concentration of $60 \mathrm{mg} / \mathrm{L}$. They found that hydrocarbon removal efficiencies higher than $97 \%$ were possible with HRT values of 8,16 and $24 \mathrm{~h}$. Accordingly, the rate of membrane fouling increased with the decrease in HRT values.

Campo et al. [52] compared data from three stand-alone treatments of shipboard slop wastewater produced by the washing of oil tankers with seawater and characterized by high salinity $(39 \mathrm{~g} / \mathrm{L}$ of $\mathrm{NaCl}$ ) and hydrocarbon contents (TPH of $135 \pm 38 \mathrm{mg} / \mathrm{L}$ ). The treatments were (1) a chemical treatment of coagulation-flocculation with aluminum sulphate as coagulant and an anionic flocculant, (2) a physical treatment of adsorption on granular activated carbon (GAC), (3) two biological treatments represented by a membrane bioreactor (MBR) and a moving bed biofilm reactor (MBBR) with soft polyurethane sponges. Both reactors were equipped with ultrafiltration hollow fiber membrane modules. To limit the fouling, each membrane was periodically backwashed (every $4 \mathrm{~min}$ for a period of $1 \mathrm{~min}$ ) by pumping a fraction of permeate back through the membrane. The bioreactors operated continuously with HRT in the range of $12-15 \mathrm{~h}$. As a result, the GAC treatment registered the highest removal efficiency of TPHs up to $85 \%$, while the coagulation-flocculation treatment reported the lowest (57\%) removal of TPHs. The 70\% TPH removal was obtained with the MBBR fed with $100 \%$ volume of slop, thus suggesting a biomass acclimation to salinity and hydrocarbons.

Alternatively, Dong et al. [53] used suspended ceramic foam carriers with a high mechanical strength, optimum density (close to water) and high porosity to treat oilfield produced water (COD of $343-365 \mathrm{mg} / \mathrm{L}$; TPH of $24-28 \mathrm{mg} / \mathrm{L}$ ) in MBBRs operating at HRT values ranging from 36 to $10 \mathrm{~h}$. The highest COD, PAH and ammonia $\mathrm{N}$ removal rates were recorded at HRT of $10 \mathrm{~h}$ in the MBBR filled with sepiolite-modified carriers characterized by a larger specific surface area for the biofilm growth, followed by the MBBR with unmodified carriers, with the lowest removal efficiency in the MBBR with the activated sludge only.

A full-scale application of continuous flow intermittent cleaning (CFIC) biofilm technology based on the MBBR concept was performed recently in the Biowater Technology AS in Norway to treat petrochemical wastewater of fluctuating concentrations with the COD ranging from 7 to $35 \mathrm{~g} / \mathrm{L}$ [7]. The CFIC reactor contained highly packed polymer biofilm carriers (over $90 \%$ filling ratio) was operated continuously at the flow rate of $240 \mathrm{~m}^{3} /$ day, resulting in over $90 \%$ COD removal. Excess biofilm/sludge was washed off during periodic washings, thus maintaining a thin and effective biofilm in the reactor.

Zhao et al. [39] investigated the use of biological aerated filter (BAF) reactors inoculated with the commercial oil-degrading inocula immobilized on a patented poly-ammoniacum carrier to pre-treat the oilfield wastewater before desalination. By operating the bioreactors for 142 days under low COD load ( $1.07 \mathrm{~kg} \mathrm{COD} / \mathrm{m}^{3}$.day) and high salinity conditions, the mean degradation efficiencies of $64-78 \%$ for total organic carbon (TOC), 86-94\% for oil and 84-90\% for PAHs were achieved. More recently, a bench-scale BAF reactor with GAC was examined for effective removal of organic matter and solids from produced water using three GAC carriers (one spent and two new) and two nutrient supplements [54]. The spent GAC with an existing biofilm from the previous treatment of surface water demonstrated up to $81 \%$ COD removal in $24 \mathrm{~h}$ (from initial COD values of $1368 \pm 312 \mathrm{mg} / \mathrm{L}$ ), indicating that appropriate GAC selection and pre-developed biofilm is critical for efficient BAF performance. Interestingly, recent evaluation of different inocula for treating high salinity produced water in a batch stirred tank bioreactor [55] revealed a higher efficiency of the acclimated indigenous halophilic microorganisms compared to that of the commercial inocula used in Reference [39].

Selected bacterial strains with broad hydrocarbon-oxidizing activities and resistance to toxic petroleum constituents were used as bioreactor inocula. For example, Khondee et al. [56] used an 
internal loop airlift bioreactor inoculated with a chitosan-immobilized bacterium Sphingobium sp. P2 for the removal of automotive lubricants from emulsified wastewater. The reactor operated continuously at the HRT of $2.0 \mathrm{~h}$ for over 70 days, resulting in the removal of $85 \pm 5 \% \mathrm{TPH}$ and $73 \pm 11 \% \mathrm{COD}$ from the carwash wastewater with $25-200 \mathrm{mg} / \mathrm{L}$ amended lubricant. Sudmalis et al. [57] demonstrated a simultaneous $n$-alkane biodegradation and production of neutral lipids in a concentrated produced water stream by Alcanivorax borkumensis SK2 as the sole reactor inoculum. $n$-Alkane removal efficiency up to $99.6 \%$, with influent alkane COD of $7.4 \mathrm{~g} / \mathrm{L}$, was achieved in a continuously operated stirred tank reactor. The simultaneous process of hydrocarbon biodegradation and production of mostly extracellular neutral lipids revealed the possibility of bioconversion of toxic industrial wastes into valuable compounds.

Fluidized bed bioreactors (FBBs) (Figure 1), in which the biomass is fixed on bed particles fluidized by liquid up-flow, were successfully applied to aerobic biological treatment of industrial and domestic wastewaters $[38,58]$. The use of smaller particles than those in MBR and MBBR systems results in much thicker biofilms and therefore FBBs are proven to be able to withstand large loads and operate at lower HRT values compared to typical bioreactor. Large biofilm-liquid interfacial area, high immobilized biomass concentration and improved mass transfer are the major advantages of this type reactors [62].

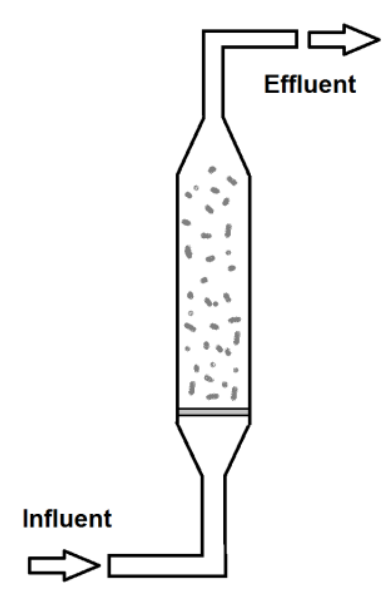

(a)

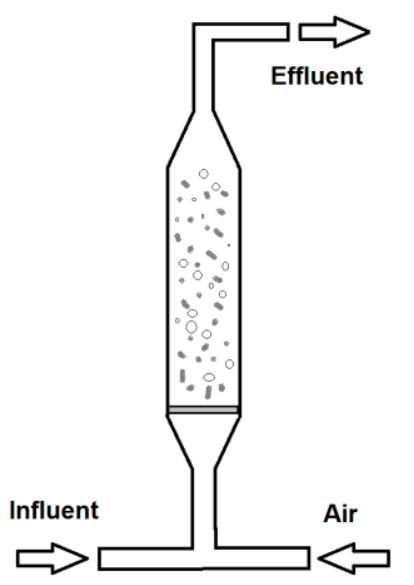

(b)

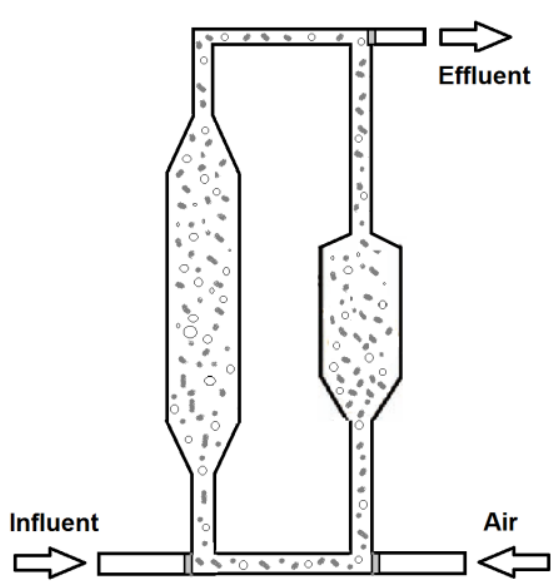

(c)

Figure 1. Different type fluidized-bed bioreactors (FBB): (a) two-phase (liquid-solid); (b) three-phase (gas-liquid-solid); (c) three-phase (gas-liquid-solid) with particle circulation.

A biotreatment of petroleum refinery wastewater was investigated in the three-phase (gas-liquid-solid) FBB, in which polypropylene particles were inoculated with the refinery activated sludge sample and fluidized by an upward flow of air [38]. Clogging and channeling of the bed were eliminated through the intensive motion of the particles. Approximately a $90 \%$ COD reduction (from 34,250 to $3100 \mathrm{mg} / \mathrm{L}$ ), was achieved after two weeks of steady-state biomass loading. More recently, a batch FBB inoculated with the pelleted mycelium of the white rot fungus Trametes versicolor ATCC 42530 was used to study the degradation of pharmaceutical micropollutants present in urban wastewaters [58]. Complete removal of 7 out of 10 initially detected pharmaceuticals, including antibiotics and non-steroid anti-inflammatory compounds, was achieved in a non-sterile treatment.

It should be noted that successful FBB treatments of hydrocarbon-containing water are often hindered by limitations of mass transfer between three phases: aqueous, hydrophobic (hydrocarbons) and solid (biocatalyst). Thus, greater requirements apply to the carrier that must have an optimal particle size and density to be easily fluidized at the operational flow rate, be non-toxic and absorbing hydrocarbons and microbial cells and be resistant to chemical and mechanical damages. We previously tested [59] three different materials, namely hydrophobized sawdust, granulated macroporous cryogel made of poly(vinyl alcohol) and sponge-like poly(acrylamide) cryogel for the immobilization of 
Rhodococcus ruber IEGM 615 and Rhodococcus opacus IEGM 249 association (Figure 2). It was found that hydrophobized sawdust had a largest surface area available for bacterial adhesion, and, as a result, demonstrated highest level of bacterial cell immobilization. This biocatalyst was used to treat synthetic petroleum wastewater in FBBs continuously operating at different flow rates $(0.6$ or $1.2 \mathrm{~mL} / \mathrm{min})$ for 3 weeks. The FBB with a faster flow rate was most successful, providing $70-100 \%$ removal of $n$-alkanes $\left(\mathrm{C}_{10}-\mathrm{C}_{19}\right)$ and $46-70 \%$ removal of 2-3-ring PAHs from contaminated water after two weeks.

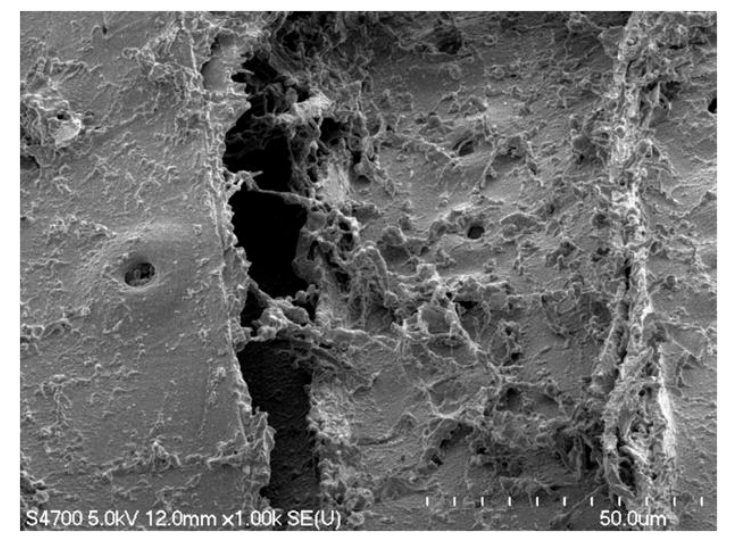

(a)

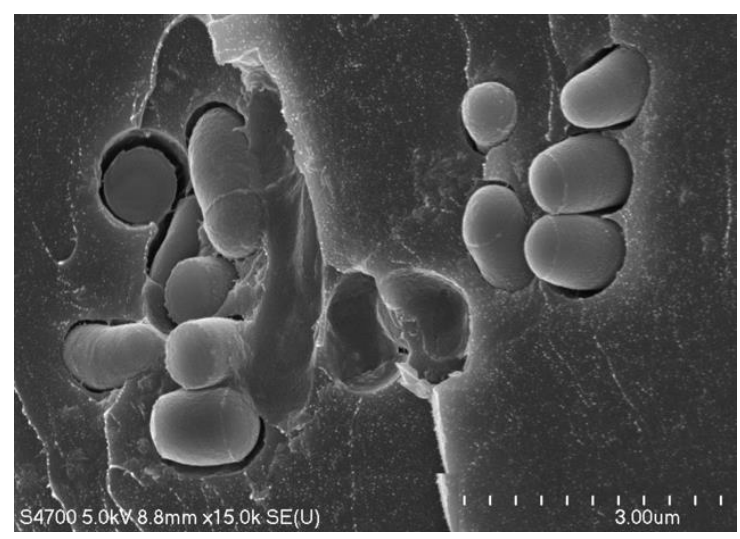

(b)

Figure 2. SEM images of Rhodococcus cells immobilized (a) on hydrophobized sawdust [41] and (b) in granulated poly(vinyl alcohol) cryogel [63].

More recently, we evaluated a feasibility of the FBB process using sawdust co-immobilized Rhodococcus cultures for the purification of highly concentrated (COD of $10.3 \mathrm{~g} / \mathrm{L}$; TPH of $3.74 \mathrm{~g} / \mathrm{L}$ ) oilfield wastewater [41], resulting in 70\% biodegradation efficiencies for alkanes and PAHs within two weeks. Furthermore, the 75-96\% removal of heavy metals ( $\mathrm{Al}, \mathrm{Cr}, \mathrm{Cu}, \mathrm{Fe}, \mathrm{Hg}, \mathrm{Zn}, \mathrm{Mn}$ ) resulted from combined effects of physical sorption by sawdust and biosorption by the Rhodococcus biomass. While a treatment of highly saline oilfield wastewater was less efficient in the FBB with Rhodococcus co-cultures immobilized in poly(vinyl alcohol) granules [60], such gel-encapsulated cells were more resistant to salinity and hydrocarbons and could be easily recovered from the bioreactor for further reuse.

\subsection{Anaerobic and Hybrid (Anaerobic-Aerobic) Bioreactors}

Anaerobic digestion has been recognized as the sustainable wastewater treatment because it requires less space, generates low sludge amount compared to aerobic treatment and produces methane as a renewable energy. Currently, anaerobic baffled reactors (ABR), sequencing batch and up-flow anaerobic sludge blanket (UASB) reactors are applied to treat oily wastewater. Selected examples of 
anaerobic bioreactors used for hydrocarbon-containing wastewater treatment are shown in Table 3. Ji et al. [43] studied an ABR start-up and operational performance (total 212 days) in treating oilfield produced water using mixed acclimated oilfield and urban sewage sludges. Such long ABR treatment under the COD load of $0.2-0.5 \mathrm{~kg} / \mathrm{m}^{3}$.day resulted in COD and oil removals of $65 \%$ and $88 \%$ for heavy oil produced water with poor nutrient (COD: N: P, 1200:15:1) and high salt concentration (1.15-1.46\%). An UASB bioreactor inoculated with digested sludge from a dairy industry was used to treat petroleum refinery effluent under mesophilic conditions $\left(38 \pm 1^{\circ} \mathrm{C}\right)$ for over120 days [44]. The authors used response surface methodology to optimize the efficient factors (influent COD of $630 \mathrm{mg} / \mathrm{L}$, upflow velocity of $0.27 \mathrm{~m} / \mathrm{h}$ and HRT of $21.4 \mathrm{~h}$ ). Under these optimum conditions, the COD removal efficiency was $76.3 \%$ and the biogas production rate was $0.25 \mathrm{~L}$ biogas/L feed day. More recently, artificial neural networks were used to model the UASB reactor behavior during $180 \mathrm{~d}$ treating petroleum refinery wastewater under six different organic loads (from 0.58 to $4.14 \mathrm{~kg} \mathrm{COD} / \mathrm{m}^{3}$.day) [64]. The highest COD removal of $82 \%$ shown in the laboratory bioreactor was confirmed by using the best selected model with the Tansig-Purelin transfer function and 12 neurons.

Table 3. Anaerobic and Hybrid (Anaerobic-Aerobic) Bioreactors Used for Hydrocarbon-Containing Wastewater Treatment.

\begin{tabular}{|c|c|c|c|c|}
\hline Wastewater Type & $\begin{array}{c}\text { Bioreactor } \\
\text { Configuration }\end{array}$ & Operational Conditions & $\begin{array}{l}\text { Treatment } \\
\text { Efficiency }\end{array}$ & Reference \\
\hline $\begin{array}{l}\text { Oilfield produced } \\
\text { water }\end{array}$ & $\mathrm{ABR}$ & $\begin{array}{l}\text { Start-up and operational } \\
\text { performance (total } 212 \text { days) with } \\
\text { mixed acclimated oilfield and } \\
\text { urban sewage sludges. }\end{array}$ & $\begin{array}{l}\text { COD and oil } \\
\text { removals of } 65 \% \\
\text { and } 88 \%\end{array}$ & {$[43]$} \\
\hline $\begin{array}{c}\text { Petroleum refinery } \\
\text { effluent }\end{array}$ & UASB & $\begin{array}{l}\text { Mesophilic conditions }\left(38 \pm 1{ }^{\circ} \mathrm{C}\right) \\
\text { for over120 days. Digested sludge } \\
\text { from a dairy industry. }\end{array}$ & $\begin{array}{l}\text { 76.3\% COD } \\
\text { removal, } 0.25 \mathrm{~L} \\
\text { biogas/L feed d }\end{array}$ & {$[44]$} \\
\hline $\begin{array}{l}\text { Petroleum refinery } \\
\text { wastewater }\end{array}$ & UASB & $\begin{array}{l}\text { Treating under six different } \\
\text { organic loads (from } 0.58 \text { to } 4.14 \mathrm{~kg} \\
\text { COD } / \mathrm{m}^{3} \cdot \text { day) during } 180 \text { days. }\end{array}$ & $\begin{array}{c}\text { COD removal of } \\
82 \%\end{array}$ & {$[64]$} \\
\hline $\begin{array}{c}\text { Heavy oil } \\
\text { wastewater }\end{array}$ & $\begin{array}{l}\text { HA-MBBR } \\
\text { O3-BAC }\end{array}$ & $\begin{array}{l}\text { Sludge from anaerobic and aerobic } \\
\text { tanks of petroleum refinery AS } \\
\text { plant. Effluent concentrations of } \\
\text { COD, oil and ammonia were } 48, \\
1.3 \text { and } 3.5 \mathrm{mg} / \mathrm{L} .\end{array}$ & $\begin{array}{l}95.8,98.9 \text { and } 94.4 \% \\
\text { removals of COD, } \\
\text { oil and ammonia }\end{array}$ & {$[47]$} \\
\hline $\begin{array}{l}\text { Acrylonitrile } \\
\text { butadiene styrene } \\
\text { resin-manufacturing } \\
\text { wastewater }\end{array}$ & $\begin{array}{l}\text { Stirred-tank HA } \\
\text { with a series of } \\
\text { algal } \\
\text { photobioreactors }\end{array}$ & $\begin{array}{l}\text { The wastewater was treated for } \\
36 \mathrm{~h} \text { in a batch process and the } \\
\text { effluent was applied to the algal } \\
\text { microcosm treatment using } \\
\text { Chlorella sp. }\end{array}$ & $\begin{array}{l}\text { COD, } \mathrm{NH} 3-\mathrm{N} \text { and } \\
\text { phosphorus } \\
\text { removal of } 83,100 \\
\text { and } 89 \%\end{array}$ & {$[65]$} \\
\hline $\begin{array}{l}\text { Petrochemical } \\
\text { wastewater }\end{array}$ & $\begin{array}{c}\text { Open } \\
\text { photobioreactors } \\
\text { integrated with } \\
\text { anaerobic/oxic } \\
\text { process }\end{array}$ & $\begin{array}{c}\text { Filamentous microalgae Tribonema } \\
\text { sp. Aeration and mixing by } \\
\text { sparging air enriched with } 1.5 \% \\
\text { CO2, gas flow rate } 0.5 \mathrm{vvm} \text {, light } \\
\text { intensity } 300 \mu \mathrm{mol} / \mathrm{m}^{2} \cdot \mathrm{s}, \\
\text { temperature } \\
25^{\circ} \mathrm{C} .\end{array}$ & $\begin{array}{c}\text { COD } \\
\text { removal of } 97.8 \%\end{array}$ & [66] \\
\hline $\begin{array}{l}\text { Petroleum refinery } \\
\text { wastewater }\end{array}$ & Pilot HyVAB & $\begin{array}{l}\text { Granular sludge from paper and } \\
\text { pulp wastewater treatment facility. } \\
\text { Continuously operating at } \\
\text { varying organic loading rates for } \\
92 \text { days. }\end{array}$ & $\begin{array}{l}86 \% \text { of the total } \\
\text { COD and } 91 \% \text { of } \\
\text { the soluble COD } \\
\text { removal }\end{array}$ & {$[15]$} \\
\hline $\begin{array}{l}\text { Metformin- } \\
\text { containing } \\
\text { wastewater }\end{array}$ & Pilot HyVAB & $\begin{array}{c}\text { Granular sludge from } \\
\text { petrochemical wastewater } \\
\text { treatment bioreactor. Co-digest } \\
\text { pharmaceutical- containing } \\
\text { wastewater with the wastewater } \\
\text { rich of easily degradable organics. }\end{array}$ & $\begin{array}{l}98 \% \text { COD removal } \\
\text { and } 100 \% \\
\text { metformin removal }\end{array}$ & {$[67]$} \\
\hline
\end{tabular}

However, anaerobic treatment alone does not always meet the requirements of water discharge and requires subsequent treatment using, for example, an aerobic process [15]. A laboratory treatment 
system consisted of UASB and aerobic packed-bed biofilm (PBB) reactors was applied to remove PAHs from refinery wastewater (COD of $435 \mathrm{mg} / \mathrm{L}$; TPH of $1520 \mathrm{mg} / \mathrm{L}$; PAH of $10.33 \mathrm{mg} / \mathrm{L}$ ), resulting in the total COD removal efficiency of $81.07 \%$ and the complete removal of three PAHs (naphthalene, phenanthrene and pyrene) after 118 days [68]. In other study, a combination of UASB and BAF reactors was used by Liu et al. [45] in a field pilot study of the treatment of heavy oil wastewater with high organic loads (COD of $129.8-1238 \mathrm{mg} / \mathrm{L}$; oil of $24.5-315.5 \mathrm{mg} / \mathrm{L}$ ) and low $\mathrm{N}$ and P contents. By operating the system for 252 days (including the start-up of 128 days), the COD, ammonia nitrogen (NH3-N) and SS were removed by $74 \%, 94 \%$ and $98 \%$, respectively. The authors suggested that most of the alkanes were degraded by the UASB process, while the BAF played important roles both in degrading organic compounds and removing NH3-N and SS. Lu et al. [46] used two MBBRs filled with suspended ceramsite for the sequential anaerobic-aerobic treatment of refinery wastewater (COD of $675-742 \mathrm{mg} / \mathrm{L} ; \mathrm{O} \& \mathrm{G}$ of $42-48 \mathrm{mg} / \mathrm{L}$ ) at the continuous flow mode for 124 days. The results showed that COD and NH3-N removal efficiencies were higher than $85 \%$ at the HRT values of 72 and $36 \mathrm{~h}$. Additionally, the removal of 16 PAHs detected in the influent was 39.4 and $74.6 \%$ for anaerobic and aerobic MBBRs, respectively.

More complex hybrid system integrating a hydrolysis acidification (HA) reactor, a MBBR and an ozonation-biologically activated carbon $\left(\mathrm{O}_{3}\right.$ - $\left.\mathrm{BAC}\right)$ unit was used to treat heavy oil wastewater (COD of 1020-1250 mg/L; oil of 108-127 mg/L), resulting in 95.898 .9 and $94.4 \%$ removals of COD, oil and ammonia, respectively [47]. The HA process improved the biodegradability of complex organics, while the MBBR process played an important role in the oxidative removal of hydrocarbons. The ozonation process further enhanced the biodegradability of the MBBR effluent and, finally, deep treatment was completed in the BAC reactor. Another novel two-stage system coupling a stirred-tank HA reactor with a series of algal photobioreactors was investigated for the treatment of acrylonitrile butadiene styrene resin-manufacturing wastewater (COD of $856 \pm 11 \mathrm{mg} / \mathrm{L}$ ) [65]. The coupling system achieved deep cleaning of the benzene-containing wastewater (COD, $\mathrm{NH}_{3}-\mathrm{N}$ and phosphorus removal rates were 83,100 and $89 \%$, respectively) while producing a considerable Chlorella sp. biomass at low cost. A filamentous microalgae Tribonema sp. was used by the same research group in open photobioreactors integrated with the traditional anaerobic/oxic process to treat low-concentration petrochemical wastewater (COD of $312.8 \pm 15.6 \mathrm{mg} / \mathrm{L}$ ) [66]. It was found that the algal post-treatment step was efficient in the removal of pollutants (COD removal rates were 71.7-97.8\%) as well as in biomass and oil accumulations.

The above laboratory and pilot studies clearly demonstrate that integrated bioreactor systems provide generally better performance for treating oily wastewater because of the synergistic effects of anaerobic and aerobic microorganisms enabling sequential degradation of recalcitrant organic compounds. However, such multi-module combinations of anaerobic and aerobic processes require large space and energy and can lead to methane emission. Recently, Wang et al. [15] tested on a pilot scale a hybrid vertical anaerobic biofilm (HyVAB) reactor, which integrated a bottom anaerobic sludge bed and a top aerobic biofilm stage [69]. The reactor was operated continuously at reducing HRT (from 55 to $12 \mathrm{~h}$ ) and increasing organic loading rate (from 3 to $33 \mathrm{~kg} \mathrm{COD} / \mathrm{m}^{3}$.day) for 92 days, treating high strength refinery wastewater, that resulted in $86 \%$ of the total COD and $91 \%$ of the soluble COD removal [15]. An advantage of this system is that due to the close integration of anaerobic and aerobic processes, dissolved gases (methane, $\mathrm{H}_{2} \mathrm{~S}$ etc.) generated in the anaerobic stage are captured and oxidized by aerobic microorganisms, thus avoiding a methane emission and providing odorless discharges to air and water. Moreover, returning the excess aerobic sludge to the bottom anaerobic part simply by gravity simplifies the sludge treatment and contributes to a methane production. Therefore, the HyVAB reactor represents a compact integrated system with low footprint, low capital expenditures and high efficiency in organic removal, energy recovery and emission prevention. Very recently, the same research group tested a pilot HyVAB reactor for the treatment of wastewater containing metformin, a widely used antidiabetic drug [67]. To achieve complete metformin removal, it was proposed to co-digest pharmaceutical-containing wastewater 
with the wastewater rich of easily degradable organics. After a period of adaptation, the reactor was able to manage organic loads of $11 \mathrm{~g} C O D /$ day and above $10 \mathrm{mg} / \mathrm{L}$ metformin, resulting in the removal of $98 \%$ COD and $100 \%$ metformin.

It should be noted that despite numerous successful laboratory and pilot-scale applications of advanced bioreactors for the treatment of oily wastewaters, their full-scale implementation is still rare. Biological processes to treat the petroleum wastewater are usually conducted in traditional activated sludge (fixed bed or suspended bed) systems or in aerated lagoons [11]. Some companies also incorporate MBRs into their treatment trains for discharge of produced waters [70].

\section{Sequentially Coupled Physico-Chemical and Biological Treatments}

In recent years, great efforts and progress has been made in the combination of biological treatment with cutting-edge physico-chemical technologies, including advanced oxidation, electrocoagulation and electroflotation, UV irradiation, sonication, bioelectrochemical processes, innovative membrane and sorption materials. Most of these technologies are used as pre-treatment methods aimed at reducing a toxic shock from concentrated wastewater to microorganisms operating in bioreactors [71]. Bahri et al. [72] reviewed four advanced oxidation processes (AOPs) - photocatalytic oxidation, Fenton/photo-Fenton oxidation, wet air oxidation and catalytic wet air oxidation, which can be used as pre-treatment methods to increase the performance capability of the biological treatment. Depending on wastewater characteristics and operational conditions, the AOP converts recalcitrant organic components into lower molecular weight compounds, which are more amenable to biological degradation and hence an easier decomposition in a biological treatment plant can be achieved. Kang et al. [73] applied a vacuum ultraviolet (VUV, $185 \mathrm{~nm}$ ) and $\mathrm{TiO}_{2}$ oxidation system for the pre-treatment of oily wastewater. The results indicated that the $\mathrm{VUV} / \mathrm{TiO}_{2}$ process reduced significantly COD, BOD and oil content and improved the biodegradability of oily wastewater, thus paving the way for subsequent biological treatment.

Pérez et al. [74] studied a sequentially coupled electrocoagulation (EC) and a fixed film aerobic bioreactor to treat highly concentrated (COD of $19.4 \mathrm{~g} / \mathrm{L}$; TPH of $10.2 \mathrm{~g} / \mathrm{L}$ ) petroleum refinery wastewater. Under the optimized EC conditions $(6.5 \mathrm{~V}, 0.1 \mathrm{M} \mathrm{NaCl}, 4$ electrodes without initial $\mathrm{pH}$ adjustment), over $88 \%$ of COD and $>80 \%$ of TPH were removed and the effluent biodegradability increased from the BOD/COD value of 0.015 up to 0.5 . Further bioreactor treatment using bacteria isolated from the wastewater and immobilized on tezontle, a red basaltic scoria, resulted in the overall removal of 95 and $98 \%$ for COD and TPH respectively after 30 days.

A combination of surfactant-modified zeolite (SMZ) adsorbent beds and an MBR was used to reduce the organic carbon content of produced water prior to reverse osmosis (RO) [75]. In the pilot plant, pre-treated produced water from gas and oil fields was cycled through the SMZ adsorbent column to remove volatile organic compounds (BTEX, acetone) and semi-volatile organics (e.g., napthalene). The effluent from the SMZ column was fed to the submerged MBR for the removal of organic acid components of TOC. Continuous operation of the SMZ/MBR system at 9.6-h HRT resulted in the overall $92 \%$ removal efficiency of the influent TOC. BTEX concentrations were reduced from the initial input level of $70 \mathrm{mg} / \mathrm{L}$ to $5 \mathrm{mg} / \mathrm{L}$ by the SMZ units and to an average of $2 \mathrm{mg} / \mathrm{L}$ after the MBR. Fakhru'l-Razi et al. [76] compared the MSBR and MSBR/RO efficiencies in treating oilfield produced water (COD of $1240 \pm 119 \mathrm{mg} / \mathrm{L} ; \mathrm{O} \& \mathrm{G}$ of $15 \pm 1.8 \mathrm{mg} / \mathrm{L}$ ). Different HRT values of 8,20 and $44 \mathrm{~h}$ were investigated in the MSBR operations and the results demonstrated that for the HRT of $20 \mathrm{~h}$, the combined COD, TOC and O\&G removal efficiencies were $90.9 \%, 92 \%$ and $91.5 \%$, respectively. The MSBR effluent concentration levels met the requirements for oil well reinjection. The RO treatment decreased the salt and organic contents to acceptable levels for irrigation and industrial re-use. Fouling of the membrane surface consisted mainly of inorganic (salts) and organic (microorganisms and their products, hydrocarbon components) substances.

A full-scale application of the integrated treatment process, including a pre-treatment (microaerobic hydrolysis and acidification, MOHA), biological treatment (A/O process) and advanced treatment 
(micro-flocculation dynasand filtration and catalytic ozonation, MFDF-CO) was demonstrated in the Chinese biggest petrochemical wastewater treatment plant [77]. The performance of the integrated process was stable and resulted in the COD reduction from 84.7 to $47.0 \mathrm{mg} / \mathrm{L}$ and removing most organic micropollutants. The final effluent showed low acute toxicity and genotoxicity. The energy demand, however, increased by $44.1 \%$ with the electricity consumption mainly from the ozone generator, leading to increased operational cost and indirect carbon emission.

Several recent studies reported a performance of microbial fuel cells (MFCs) and their reactor systems for simultaneous energy production and wastewater treatment using single bacterial cultures and microbial consortia. Using a wild-type bacterium Pseudomonas putida BCRC 1059, refinery wastewater (COD of $2213 \mathrm{mg} / \mathrm{L}$ ) was treated in a single chamber air-cathode MFC and generated electric current over four-batch cycles for 63 cumulative days [78]. A maximum voltage of $355 \mathrm{mV}$ was obtained with the highest power density of $0.005 \mathrm{~mW} / \mathrm{cm}^{2}$ in the third cycle with a maximum current density of $0.015 \mathrm{~mA} / \mathrm{cm}^{2}$ regarding the external resistor of $1000 \Omega$. A maximum coulombic efficiency of $6 \times 10^{-2} \%$ was obtained in the fourth cycle and the COD removal efficiency of $30 \%$ was reached as a function of time. Very recently, a bioelectrochemical treatment of synthetic produced water (contained $0.8 \mathrm{~g} / \mathrm{L}$ of engine oil; TPH of $124-130 \mathrm{mg} / \mathrm{L}$ ) and simultaneous bioelectrogenesis was studied in single and dual chamber MFCs [79]. Among both configurations, dual chamber MFC showed higher efficiency with respect to bioelectrogenesis, sulfate removal, COD and TPH reductions. The estimated polarization behavior of both MFCs also indicated an effective response of the electroactive anode biofilm.

Microbial communities and bioelectrochemical activities were evaluated in two laboratory-scale MFC reactors inoculated by petrochemical industrial or domestic microbial consortia for degrading 2,4-dichlorophenol and producing electricity [80]. Wastewater-inoculated MFCs were capable of simultaneous energy generation and phenolic degradation. Members of bacterial genera Arcobacter, Aeromonas, Pseudomonas, Acinetobacter, Cloacibacterium and Shewanella were found to be important bacteria for 2,4-DCP degradation while Bacillus sp. dominated in the industrial consortium was contributing to higher electricity production. Cloacibacterium sp. was identified for the first time to contribute to phenol degradation in MFC.

A laboratory performance of integrated constructed wetland and MFC reactors (CW-MFC) to treat oil-contaminated wastewater (COD of $520 \pm 42 \mathrm{mg} / \mathrm{L}$; oil content of $235 \pm 12 \mathrm{mg} / \mathrm{L}$ ) was compared with the MFC and CW alone [81]. The COD removals of three reactors were between $73 \%$ and $75 \%$ and oil removals were over $95.7 \%$. Compared with MFC, the CW-MFC with a $\mathrm{MnO}_{2}$ modified cathode produced higher power density and output voltage. Maximum power densities of CW-MFC and MFC were $3868 \mathrm{~mW} / \mathrm{m}^{3}\left(102 \mathrm{~mW} / \mathrm{m}^{2}\right)$ and $3044 \mathrm{~mW} / \mathrm{m}^{3}\left(80 \mathrm{~mW} / \mathrm{m}^{2}\right)$, respectively. Wetland plants in CW-MFC play a positive role for the reactor cathode potential.

\section{Conclusions}

Bioreactor-based methods are proved as suitable techniques for the treatment of industrial hydrocarbon-containing wastewater due to their substantial advantages over traditional activated sludge systems, such as more precise control and management of biodegradation parameters, increased mass transfer between aqueous, hydrophobic (hydrocarbons) and solid (biocatalyst) phases and higher resistance of the immobilized biomass to toxic effects. However, their extensive implementation is hindered by relatively high operational and maintenance costs. This leads to the search for economical compact bioreactor designs, which however retain sufficient treatment efficiency. There are a great variety of advanced constructions, for example, stirred-tank, membrane, packed-bed and fluidized-bed bioreactors that can be operated in aerobic, anaerobic or coupled anaerobic-aerobic mode. Several laboratory and pilot studies demonstrated better performance of hybrid anaerobic-aerobic systems because of the synergistic effects of anaerobic and aerobic microorganisms in degrading complex recalcitrant organics. Therefore, future efforts may be focused on improving such hybrid systems to reduce space and energy consumption as well as gas and odor emissions [15]. It exposes 
new requirements to microbial inocula, emphasizing the need for a deeper study of interactions in anaerobic and aerobic microbial communities under anaerobic, microaerophilic and aerobic conditions using genomics and metabolomics tools [82,83]. Genetic tools can also be useful for detecting possible pathogens in bioreactor effluents and sludges. Considering the main challenges of oily wastewater treatment arising from high strength and a complexity of effluents, a pre-treatment using physico-chemical technologies aimed at reducing a toxic shock from concentrated wastewater to microorganisms operating in bioreactors, is essential [71]. Therefore, a complex physico-chemical and biological approach seems promising for the removal of many contaminants with diverse chemical structures and biodegradabilities.

Funding: This research was funded by the Ministry of Science and Higher Education of the Russian Federation (State Tasks 6.3330.2017/4.6, AAAAA19-119112290010-7) and the Russian Science Foundation (18-14-00140).

Conflicts of Interest: The authors declare no conflict of interest.

\section{References}

1. Alva-Argáez, A.; Kokossis, A.C.; Smith, R. The design of water-using systems in petroleum refining using a water-pinch decomposition. Chem. Eng. J. 2007, 128, 33-46. [CrossRef]

2. Wastewater Management-A UN-Water Analytical Brief. 2015. Available online: https://www.unwater.org/ publications/wastewater-management-un-water-analytical-brief/ (accessed on 14 November 2019).

3. Diya'uddeen, B.H.; Daud, W.M.A.W.; Abdul Aziz, A.R. Treatment technologies for petroleum refinery effluents: A review. Process Saf. Environ. Prot. 2011, 89, 95-105. [CrossRef]

4. Jamaly, S.; Giwa, A.; Hasan, S.W. Recent improvements in oily wastewater treatment: Progress, challenges, and future opportunities. J. Environ. Sci. 2015, 37, 15-30. [CrossRef] [PubMed]

5. Wei, X.; Zhang, S.; Han, Y.; Wolfe, F.A. Treatment of petrochemical wastewater and produced water from oil and gas. Water Environ. Res. 2019, 91, 1025-1033. [CrossRef] [PubMed]

6. Sanchez-Salas, J.L.; Raynal Gutierrez, M.E.; Bandala, E.R. Aerobic treatment of petroleum industry effluents. In Current Developments in Biotechnology and Bioengineering: Biological Treatment of Industrial Effluents; Lee, D.-J., Hallenbeck, P., Ngo, H.H., Jegatheesan, V., Pandey, A., Eds.; Elsevier: Amsterdam, The Netherlands, 2016; Chapter 3; pp. 79-102.

7. Ghimire, N.; Wang, S. Biological treatment of petrochemical wastewater. In Petroleum Chemicals—Recent Insight; Zoveidavianpoor, M., Ed.; IntechOpen: London, UK, 2018. Available online: https://www.intechopen.com/ books/petroleum-chemicals-recent-insight/biological-treatment-of-petrochemical-wastewater (accessed on 11 November 2019). [CrossRef]

8. Bakke, T.; Klungsøyr, J.; Sanni, S. Environmental impacts of produced water and drilling waste discharges from the Norwegian offshore petroleum industry. Mar. Environ. Res. 2013, 92, 154-169. [CrossRef]

9. Ottaviano, J.G.; Cai, J.; Murphy, R.S. Assessing the decontamination efficiency of a three-component flocculating system in the treatment of oilfield-produced water. Water Res. 2014, 52, 122-130. [CrossRef]

10. Veil, J.A. U.S. Produced Water Volumes and Management Practices in 2012; Veil Environmental, LLC: Annapolis, MD, USA, 2015; 119p.

11. Barthe, P.; Chaugny, M.; Roudier, S.; Sancho, L.D. EU Best Available Techniques (BAT): Reference Document for the Refining of Mineral Oil and Gas; Publications Office of the European Union: Luxembourg, 2015. [CrossRef]

12. Botalova, O.; Schwarzbauer, J.; Frauenrath, T.; Dsikowitzky, L. Identification and chemical characterization of specific organic constituents of petrochemical effluents. Water Res. 2009, 43, 3797-3812. [CrossRef]

13. Wu, P.; Jiang, L.Y.; He, Z.; Song, Y. Treatment of metallurgical industry wastewater for organic contaminant removal in China: Status, challenges, and perspectives. Environ. Sci. Water Res. Technol. 2017, 3, 1015-1031. [CrossRef]

14. Thornton, I.; Butler, D.; Docx, P.; Hession, M.; Makropoulos, C.; McMullen, M.; Nieuwenhuijsen, M.; Pitman, A.; Rautiu, R.; Sawyer, R.; et al. Pollutants in Urban Waste Water and Sewage Sludge; EU Final Report; ICON: London, UK, 2001; 244p.

15. Wang, S.; Ghimire, N.; Xin, G.; Janka, E.; Bakke, R. Efficient high strength petrochemical wastewater treatment in a hybrid vertical anaerobic biofilm (HyVAB) reactor: A pilot study. Water Pract. Technol. 2017, 12, 501-513. [CrossRef] 
16. Rizzardini, C.B.; Goi, D. Sustainability of domestic sewage sludge disposal. Sustainability 2014, 6, $2424-2434$. [CrossRef]

17. Varyushina, G. Solutions for the disposal of industrial and rain wastewater of transport enterprises in Moscow. MATEC Web Conf. 2018, 144, 05007. [CrossRef]

18. Kuyukina, M.S.; Ivshina, I.B.; Makarov, S.O.; Philp, J.C. Risk assessment and management of terrestrial ecosystems exposed to petroleum contamination. In Environmental Contamination; Srivastava, J.K., Ed.; InTech: London, UK, 2012; Chapter 10; pp. 177-198.

19. Philp, J.; Stainsby, F.; Dunbar, S. Partitioning and Bioavailability. In Water Encyclopedia; Hoboken, N.J., Ed.; Wiley: Hoboken, NJ, USA, 2005. [CrossRef]

20. Disko West. A Strategic Environmental Impact Assessment of Hydrocarbon Activities; Scientific Report from DCE—Danish Centre for Environment and Energy; Mosbech, A., Schiedek, D., Dünweber, M., Eds.; Aarhus University, DCE: Aarhus, Denmark, 2013; No. 71; 306p.

21. Kassotis, C.D.; Tillitt, D.E.; Lin, C.H.; McElroy, J.A.; Nagel, S.C. Endocrinedisrupting chemicals and oil and natural gas operations: Potential environmental contamination and recommendations to assess complex environmental mixtures. Environ. Health Perspect. 2016, 124, 256-264. [CrossRef] [PubMed]

22. Neff, J.; Lee, K.; DeBlois, E.M. Produced Water: Overview of Composition, Fates, and Effects. In Produced Water; Lee, K., Neff, J., Eds.; Springer: Berlin/Heidelberg, Germany, 2011; pp. 3-54. [CrossRef]

23. Neuparth, T.; Moreira, S.M.; Santos, M.M.; Reis-Henriques, M.A. Review of oil and HNS accidental spills in Europe: Identifying major environmental monitoring gaps and drawing priorities. Mar. Pollut. Bull. 2012, 64, 1085-1095. [CrossRef]

24. Osuji, L.C.; Nwoye, I. An appraisal of the impact of petroleum hydrocarbons on soil fertility: The Owaza experience. Afr. J. Agric. Res. 2007, 2, 318-324.

25. Sutton, N.B.; Maphosa, F.; Morillo, J.A.; Al-Soud, W.A.; Langenhoff, A.A.M.; Grotenhuis, T.; Rijnaarts, H.H.M.; Smidt, H. Impact of long-term diesel contamination on soil microbial community structure. Appl. Environ. Microbiol. 2013, 79, 619-630. [CrossRef] [PubMed]

26. Hayat, S.; Ahmad, I.; Azam, Z.M.; Ahmad, A.; Inam, A.; Samiullah. Effect of long-term application of oil refinery wastewater on soil health with special reference to microbiological characteristics. Bioresour. Technol. 2002, 84, 159-163. [CrossRef]

27. Echchelh, A.; Hess, T.; Sakrabani, R. Reusing oil and gas produced water for irrigation of food crops in drylands. Agric. Water Manag. 2018, 206, 124-134. [CrossRef]

28. Tasker, T.L.; Burgos, W.D.; Piotrowski, P.; Castillo-Meza, L.; Blewett, T.A.; Ganow, K.B.; Stallworth, A.; Delompré, P.L.M.; Goss, G.G.; Fowler, L.B.; et al. Environmental and human health impacts of spreading oil and gas wastewater on roads. Environ. Sci. Technol. 2018, 52, 7081-7091. [CrossRef]

29. Campos, J.C.; Borges, R.M.H.; Oliveira Filho, A.M.; Nobrega, R.; Sant'anna, G.L., Jr. Oilfield wastewater treatment by combined microfiltration and biological processes. Water Res. 2002, 36, 95-104. [CrossRef]

30. Sirivedhin, T.; McCue, J.; Dallbauman, L. Reclaiming produced water for beneficial use: Salt removal by electrodialysis. J. Membr. Sci. 2004, 243, 335-343. [CrossRef]

31. El-Naas, M.H.; Al-Zuhair, S.; Alhaija, M.A. Reduction of COD in refinery wastewater through adsorption on date-pit activated carbon. J. Hazard. Mater. 2010, 173, 750-757. [CrossRef] [PubMed]

32. dos Santos, E.V.; Bezerra Rocha, J.H.; de Araújo, D.M.; de Moura, D.C.; Martínez-Huitle, C.A. Decontamination of produced water containing petroleum hydrocarbons by electrochemical methods: A minireview. Environ. Sci. Pollut. Res. 2014, 21, 8432-8441. [CrossRef] [PubMed]

33. Kalmykova, Y.; Moona, N.; Strömvalla, A.-M.; Björklund, K. Sorption and degradation of petroleum hydrocarbons, polycyclic aromatic hydrocarbons, alkylphenols, bisphenol A and phthalates in landfill leachate using sand, activated carbon and peat filters. Water Res. 2014, 56, 246-257. [CrossRef] [PubMed]

34. Tellez, G.; Nirmalakhandan, N.; Gardea-Torresdey, J.L. Kinetic evaluations of a field-scale activated sludge system for removing petroleum hydrocarbons from oilfield-produced water. Environ. Prog. 2005, 24, 96-104. [CrossRef]

35. Huang, C.; Shi, Y.; Gamal El-Din, M.; Liu, Y. Treatment of oil sands process-affected water (OSPW) using ozonation combined with integrated fixed-film activated sludge (IFAS). Water Res. 2015, 85, 167-176. [CrossRef] [PubMed]

36. Ji, G.D.; Sun, T.; Zhou, Q.X.; Sui, X.; Chang, S.J.; Li, P.J. Constructed subsurface flow wetland for treating heavy oil-produced water of the Liaohe Oilfield in China. Ecol. Eng. 2002, 18, 459-465. [CrossRef] 
37. Kanagy, L.E.; Johnson, B.M.; Castle, J.W.; Rodgers, J.H., Jr. Design and performance of a pilot-scale constructed wetland treatment system for natural gas storage produced water. Bioresour. Technol. 2008, 99, 1877-1885. [CrossRef]

38. Sokół, W. Treatment of refinery wastewater in a three-phase fluidised bed bioreactor with a low density biomass support. Biochem. Eng. J. 2003, 15, 1-10. [CrossRef]

39. Zhao, X.; Wang, Y.; Ye, Z.; Borthwick, A.G.L.; Ni, J. Oil field wastewater treatment in Biological Aerated Filter by immobilized microorganisms. Process Biochem. 2006, 41, 1475-1483. [CrossRef]

40. Gargouri, B.; Karray, F.; Mhiri, N.; Aloui, F.; Sayadi, S. Application of a continuously stirred tank bioreactor (CSTR) for bioremediation of hydrocarbon-rich industrial wastewater effluents. J. Hazard. Mater. 2011, 189, 427-434. [CrossRef]

41. Kuyukina, M.S.; Ivshina, I.B.; Serebrennikova, M.K.; Krivoruchko, A.V.; Korshunova, I.O.; Peshkur, T.A.; Cunningham, C.J. Oilfield wastewater biotreatment in a fluidized-bed bioreactor using co-immobilized Rhodococcus cultures. J. Environ. Chem. Eng. 2017, 5, 1252-1260. [CrossRef]

42. Parker, W.; Farquhar, G.J. Treatment of a petrochemical wastewater in an anaerobic packed bed reactor. Water Qual. Res. J. 1989, 24, 195-206. [CrossRef]

43. Ji, G.D.; Sun, T.H.; Ni, J.R.; Tong, J.J. Anaerobic baffled reactor (ABR) for treating heavy oil produced water with high concentrations of salt and poor nutrient. Bioresour. Technol. 2009, 100, 1108-1114. [CrossRef] [PubMed]

44. Rastegar, S.O.; Mousavi, S.M.; Shojaosadati, S.A.; Sheibani, S. Optimization of petroleum refinery effluent treatment in a UASB reactor using response surface methodology. J. Hazard. Mater. 2011, 197, $26-32$. [CrossRef] [PubMed]

45. Liu, G.; Ye, Z.; Tong, K.; Zhang, Y. Biotreatment of heavy oil wastewater by combined upflow anaerobic sludge blanket and immobilized biological aerated filter in a pilot-scale test. Biochem. Eng. J. 2013, 72, 48-53. [CrossRef]

46. Lu, M.; Gu, L.P.; Xu, W.H. Treatment of petroleum refinery wastewater using a sequential anaerobic-aerobic moving-bed biofilm reactor based on suspended ceramsite. Water Sci. Technol. 2013, 67, 1976-1983. [CrossRef] [PubMed]

47. Zheng, T. A compact process for treating oilfield wastewater by combining hydrolysis acidification, moving bed biofilm, ozonation and biologically activated carbon techniques. Environ. Technol. 2016, 37, 1171-1178. [CrossRef]

48. Seo, D.C.; Lee, H.J.; Hwang, H.N.; Park, M.R.; Kwak, N.W.; Cho, I.J.; Cho, J.S.; Seo, J.Y.; Joo, W.H.; Park, K.H.; et al. Treatment of non-biodegradable cutting oil wastewater by ultrasonication-Fenton oxidation process. Water Sci. Technol. 2007, 55, 251-259. [CrossRef]

49. Malakahmad, A.; Hasani, A.; Eisakhani, M.; Isa, M.H. Sequencing batch reactor (SBR) for the removal of $\mathrm{Hg}^{2+}$ and $\mathrm{Cd}^{2+}$ from synthetic petrochemical factory wastewater. J. Hazard. Mater. 2011, 191, 118-125. [CrossRef]

50. Lee, L.; Hu, J.Y.; Ong, S.L.; Ng, W.J.; Ren, J.H.; Wong, S.H. Two-stage SBR for treatment of oil refinery wastewater. Water Sci. Technol. 2004, 50, 243-249. [CrossRef]

51. Shariati, S.R.P.; Bonakdarpour, B.; Zare, N.; Ashtiani, F.Z. The effect of hydraulic retention time on the performance and fouling characteristics of membrane sequencing batch reactors used for the treatment of synthetic petroleum refinery wastewater. Bioresour. Technol. 2011, 102, 7692-7699. [CrossRef] [PubMed]

52. Campo, R.; Giustra, M.G.; De Marchis, M.; Freni, G.; Di Bella, G. Characterization and treatment proposals of shipboard slop wastewater contaminated by hydrocarbons. Water 2017, 9, 581. [CrossRef]

53. Dong, Z.; Lu, M.; Huang, W.; Xu, X. Treatment of oilfield wastewater in moving bed biofilm reactors using a novel suspended ceramic biocarrier. J. Hazard. Mater. 2011, 196, 123-130. [CrossRef] [PubMed]

54. Riley, S.M.; Ahoor, D.C.; Cath, T.Y. Enhanced biofiltration of O\&G produced water comparing granular activated carbon and nutrients. Sci. Total Environ. 2018, 640-641, 419-428.

55. Pendashteh, A.R.; Chaibakhsh, N.; Ahmadun, F.-R. Biological treatment of high salinity produced water by microbial consortia in a batch stirred tank reactor: Modelling and kinetics study. Chem. Eng. Commun. 2018, 205, 387-401. [CrossRef]

56. Khondee, N.; Tathong, S.; Pinyakong, O.; Powtongsook, S.; Chatchupong, T.; Ruangchainikom, C.; Luepromchai, E. Airlift bioreactor containing chitosan-immobilized Sphingobium sp. P2 for treatment of lubricants in wastewater. J. Hazard. Mater. 2012, 213-214, 466-473. [CrossRef] [PubMed] 
57. Sudmalis, D.; Da Silva, P.; Temmink, H.; Bijmans, M.M.; Pereira, M.A. Biological treatment of produced water coupled with recovery of neutral lipids. Water Res. 2018, 147, 33-42. [CrossRef]

58. Cruz-Morató, C.; Ferrando-Climent, L.; Rodriguez-Mozaz, S.; Barceló, D.; Marco-Urrea, E.; Vicent, T.; Sarrà, M. Degradation of pharmaceuticals in non-sterile urban wastewater by Trametes versicolor in a fluidized bed bioreactor. Water Res. 2013, 47, 5200-5210.

59. Kuyukina, M.S.; Ivshina, I.B.; Serebrennikova, M.K.; Krivorutchko, A.B.; Podorozhko, E.A.; Ivanov, R.V.; Lozinsky, V.I. Petroleum-contaminated water treatment in a fluidized-bed bioreactor with immobilized Rhodococcus cells. Int. Biodeterior. Biodegrad. 2009, 63, 427-432. [CrossRef]

60. Serebrennikova, M.K.; Golovina, E.E.; Kuyukina, M.S.; Ivshina, I.B. A consortium of immobilized rhodococci for oilfield wastewater treatment in a column bioreactor. Appl. Biochem. Microbiol. 2017, 53, 435-440. [CrossRef]

61. Dickhout, J.M.; Moreno, J.; Biesheuvel, P.M.; Boels, L.; Lammertink, R.G.H.; de Vos, W.M. Produced water treatment by membranes: A review from a colloidal perspective. J. Colloid Interface Sci. 2017, 487, 523-534. [CrossRef] [PubMed]

62. Nelson, M.J.; Nakhla, G.; Zhu, J. Fluidized-bed bioreactor applications for biological wastewater treatment: A review of research and developments. Engineering 2017, 3, 330-342. [CrossRef]

63. Kuyukina, M.S.; Ivshina, I.B.; Gavrin, Y.A.; Podorozhko, E.A.; Lozinsky, V.I.; Jeffree, C.E.; Philp, J.C. Immobilization of hydrocarbon-oxidizing bacteria in poly(vinyl alcohol) cryogels hydrophobized using a biosurfactant. J. Microbiol. Methods 2006, 65, 596-603. [CrossRef] [PubMed]

64. Gasim, H.A.; Kutty, S.R.M.; Hasnain Isa, M.; Alemu, L.T. Optimization of anaerobic treatment of petroleum refinery wastewater using artificial neural networks. Res. J. Appl. Sci. Eng. Technol. 2013, 6, 2077-2082. [CrossRef]

65. Huo, S.; Zhu, F.; Zou, B.; Xu, L.; Cui, F.; You, W. A two-stage system coupling hydrolytic acidification with algal microcosms for treatment of wastewater from the manufacture of acrylonitrile butadiene styrene (ABS) resin. Biotechnol. Lett. 2018, 40, 689-696. [CrossRef]

66. Huo, S.; Chen, J.; Chen, X.; Wang, F.; Xu, L.; Zhu, F.; Guo, D.; Li, Z. Advanced treatment of the low concentration petrochemical wastewater by Tribonema sp. microalgae grown in the open photobioreactors coupled with the traditional Anaerobic/Oxic process. Bioresour. Technol. 2018, 270, 476-481. [CrossRef]

67. Janka, E.; Carvajal, D.; Wang, S.; Bakke, R.; Dinamarca, C. Treatment of metformin-containing wastewater by a hybrid vertical anaerobic biofilm-reactor (HyVAB). Int. J. Environ. Res. Public Health 2019, 16, 4125. [CrossRef]

68. Nasirpour, N.; Mousavi, S.M.; Shojaosadati, S.A. Biodegradation potential of hydrocarbons in petroleum refinery effluents using a continuous anaerobic-aerobic hybrid system. Korean J. Chem. Eng. 2015, 32, 874-881. [CrossRef]

69. Phattaranawik, J.; Leiknes, T. Study of hybrid vertical anaerobic sludge-aerobic biofilm membrane bioreactor for wastewater treatment. Water Environ. Res. 2010, 82, 273-280. [CrossRef]

70. U.S. Environmental Protection Agency. Detailed Study of the Centralized Waste Treatment Point Source Category for Facilities Managing Oil and Gas Extraction Wastes. EPA-821-R-18-004; U.S. EPA: Washington, DC, USA, 2018; 262p.

71. Prabakar, D.; Suvetha, K.S.; Manimudi, V.T.; Mathimani, T.; Kumar, G.; Rene, E.R.; Pugazhendhi, A. Pretreatment technologies for industrial effluents: Critical review on bioenergy production and environmental concerns. J. Environ. Manag. 2018, 218, 165-180. [CrossRef]

72. Bahri, M.; Mahdavi, A.; Mirzaei, A.; Mansouri, A.; Haghighat, F. Integrated oxidation process and biological treatment for highly concentrated petrochemical effluents: A review. Chem. Eng. Process. Process Intensif. 2018, 125, 183-196. [CrossRef]

73. Kang, J.; Lu, L.; Zhan, W.; Li, B.; Li, D.; Ren, Y.; Liu, D. Photocatalytic pretreatment of oily wastewater from the restaurant by a vacuum ultraviolet $/ \mathrm{TiO}_{2}$ system. J. Hazard. Mater. 2011, 186, 849-854. [CrossRef] [PubMed]

74. Pérez, L.S.; Rodriguez, O.M.; Reyna, S.; Sánchez-Salas, J.L.; Lozada, J.D.; Quiroz, M.A.; Bandala, E.R. Oil refinery wastewater treatment using coupled electrocoagulation and fixed film biological processes. Phys. Chem. Earth Parts A/B/C 2016, 91, 53-60. 
75. Kwon, S.; Sullivan, E.J.; Katz, L.; Kinney, K.A.; Bowman, R.S. Pilot scale test of a produced water-treatment system for initial removal of organic compounds. In Proceedings of the SPE Annual Technical Conference and Exhibition, Denver, CO, USA, 21-24 September 2008. SPE-116209-MS. [CrossRef]

76. Fakhru'l-Razi, A.; Pendashteh, A.; Abidin, Z.Z.; Abdullah, L.C.; Biak, D.R.A.; Madaeni, S.S. Application of membrane-coupled sequencing batch reactor for oilfield produced water recycle and beneficial re-use. Bioresour. Technol. 2010, 101, 6942-6949. [CrossRef] [PubMed]

77. Wu, C.; Li, Y.; Zhou, Y.; Li, Z.; Zhang, S.; Liu, H. Upgrading the Chinese biggest petrochemical wastewater treatment plant: Technologies research and full scale application. Sci. Total Environ. 2018, 633, 189-197. [CrossRef] [PubMed]

78. Majumder, D.; Maity, J.; Tseng, M.-J.; Nimje, V.; Chen, H.-R.; Chen, C.-C.; Chang, Y.-F.; Yang, T.-C.; Chen, C.-Y. Electricity generation and wastewater treatment of oil refinery in microbial fuel cells using Pseudomonas putida. Int. J. Mol. Sci. 2014, 15, 16772-16786. [CrossRef] [PubMed]

79. Mohanakrishna, G.; Al-Raoush, R.I.; Abu-Reesh, I.M.; Aljaml, K. Removal of petroleum hydrocarbons and sulfates from produced water using different bioelectrochemical reactor configurations. Sci. Total Environ. 2019, 665, 820-827. [CrossRef]

80. Hassan, H.; Jin, B.; Donner, E.; Vasileiadis, S.; Saint, C.; Dai, S. Microbial community and bioelectrochemical activities in MFC for degrading phenol and producing electricity: Microbial consortia could make differences. Chem. Eng. J. 2018, 332, 647-657. [CrossRef]

81. Yang, Q.; Wu, Z.; Liu, L.; Zhang, F.; Liang, S. Treatment of oil wastewater and electricity generation by integrating constructed wetland with microbial fuel cell. Materials 2016, 9, 885. [CrossRef]

82. Tang, Y.; Shigematsu, T.; Ikbal; Morimura, S.; Kida, K. The effects of micro-aeration on the phylogenetic diversity of microorganisms in a thermophilic anaerobic municipal solid-waste digester. Water Res. 2004, 38, 2537-2550. [CrossRef]

83. Yang, C.; Zhang, W.; Liu, R.; Li, Q.; Li, B.; Wang, S.; Song, C.; Qiao, C.; Mulchandani, A. Phylogenetic diversity and metabolic potential of activated sludge microbial communities in full-scale wastewater treatment plants. Environ. Sci. Technol. 2011, 45, 7408-7415. [CrossRef] [PubMed] 